\title{
Influence of $\mathrm{GA}_{3}$ and Date of Sowing on Growth and Development of Custard Apple Seedlings
}

\author{
Pritee Rahangdale $^{1}$, S.K. Pandey ${ }^{1}$ and D.K. Jayswal ${ }^{2}$ \\ ${ }^{1}$ Department of Horticulture, Jawaharlal Nehru Krishi Vishwa Vidyalaya, \\ Jabalpur (M.P.) - 482004, India \\ ${ }^{2}$ NAHEP, Krishi Anusandhan Bhawan - II, ICAR, Pusa, New Delhi-110 012, India \\ *Corresponding author
}

\section{Keywords}

Custard apple,

GA3, Fresh weight,

Dry weight, Plant

height, Stem girth

Article Info

Accepted:

12 December 2018

Available Online:

10 January 2019

\section{A B S T R A C T}

A field experiment was conducted at fruit research station, Imliya, Jawaharlal Nehru Krishi Vishwa Vidyalaya, Jabalpur to study the influence of $\mathrm{GA}_{3}$ and date of sowing on growth and development of custard apple seedlings. Significantly, maximum fresh weight of roots $(0.75 \mathrm{~g})$, dry weight of root $(0.20 \mathrm{~g})$ and total dry matter $(0.37 \mathrm{~g})$ were obtained at 120 days after germination under $500 \mathrm{ppm} \mathrm{GA}_{3}$ treatment. Minimum of these attributes was registered with untreated seeds. Among different sowing dates, $\mathrm{D}_{4}$ recorded maximum fresh weight of roots $(0.87 \mathrm{~g})$, dry weight of roots $(0.24 \mathrm{~g})$ and total dry matter $(0.370 \mathrm{~g})$, while $\mathrm{D}_{1}$ recorded minimum of these attributes. However, When seeds were treated with $500 \mathrm{ppm} \mathrm{GA}_{3}$ increased the height of the plants and maximum was recorded $(4.24,5.64$, 9.79 and $12.86 \mathrm{~cm})$, girth of stem $(1.20,2.10,2.93$ and $4.68 \mathrm{~mm})$ and number of leaves per seedlings $(4.18,6.27,9.42$ and 13.86) at all stage of observations i.e. 30, 60, 90 and 120 days after sowing respectively. Whereas, treatment control gave minimum plant height, girth of stem and number of leaves per seedling at all the stage of observations. Interaction effect of $\mathrm{GA}_{3}$ and date of sowing was found significant and maximum fresh weight, dry weight, total dry matter, plant height, girth of stem and number of leaves per seedling was recorded with $\mathrm{D}_{4} \mathrm{G}_{3}$.

\section{Introduction}

Custard apple (Annona squamosa L.) is one of the delicious fruits relished by many for table purpose, pleasant flavor; mild aroma and sweet taste have a universal acceptance. It is also known by different names such as sugar apple, Sharifa, Sitaphal and Attichaka in different parts of growing regions. It is widely cultivated in Andhra Pradesh, Maharashtra,
Karnataka, Bihar, Orissa, Assam and Tamil Nadu beside Madhya Pradesh and Chhattisgarh. It has gained commercial significance and exclusive orchards are emerging in Andhra Pradesh and Maharashtra. Custard apple is propagated both through seeds and vegetative methods. Seed propagation is even now widely fallowed resulting in great variability in seedling population. Seeds extracted from ripe fruits 
are used for sowing. The use of plant growth regulators in proper concentration with scarification may regulate seed germination and seedling growth behavior in many fruit crops. Pre-sowing treatment of growth regulators could lead to increase seed germination and enhancement of seedling growth. A low concentration of plant growth regulators may be ineffective; on the other hand, higher concentration may inhibit the growth. Seed without use of growth regulators showed poor response for germination and subsequent growth. Plant growth regulators like $\mathrm{GA}_{3}$, IBA, and IAA enhance the germination, growth and survival of seedlings. $\mathrm{GA}_{3}$ are used for weakening of the seed coat so that the emergence of radical and plumule is positively influenced for root and shoot formation. Custard apple seed does not germinate immediate after extraction due to long period of dormancy. Therefore, seeds are sown in the rainy season after long period of storage for rising of seedlings. Looking to the above mentioned fact, the experiment was carried out to study the change in growth and development of custard apple seedlings after application of $\mathrm{GA}_{3}$ concentrations and keeping different date of sowing.

\section{Materials and Methods}

The present investigation was carried out at fruit research station, Imalia, Jawaharlal Nehru Krishi Vishwa Vidyalaya, Jabalpur (M.P.) during November 2013 to April 2014. Selected well ripened healthy and disease free 58 fruits of custard apple were taken for seed extraction. Seeds were separated from pulp and washed properly in clean water. Healthy and well developed seeds were selected from the extracted seeds. 720 seeds were taken for each treatment in each replication. The experiment consisted of two factor; i.e. factor (A) date of sowing which are denoted by $\mathrm{D}_{1}$ $\left(2^{\text {nd }}\right.$ Nov., freshly extracted seed $), D_{2}\left(5^{\text {th }}\right.$ Nov., 3 days after extracted seed $), D_{3}\left(8^{\text {th }}\right.$
Nov., 6 days after extracted seed $), D_{4}\left(11^{\text {th }}\right.$ Nov., 9 days after extracted seed) and factor (B) $\mathrm{GA}_{3}$ concentration; $\mathrm{G}_{0}$ (control), $\mathrm{G}_{1}(200$ ppm), $G_{2}(400 \mathrm{ppm}), \mathrm{G}_{3}(500 \mathrm{ppm})$.The preparation of $\mathrm{GA}_{3}$ solutions (200, 400 and 500 ppm concentration) from $200 \mathrm{mg}, 400$ $\mathrm{mg}$ and $500 \mathrm{mg}$ of $\mathrm{GA}_{3}$ respectively were taken and each of dissolved separately in 5-10 $\mathrm{ml}$ of ethyl alcohol and then the volume was made to $1000 \mathrm{ml}$ by adding distilled water. The extracted 50 seeds were soaked for 12 hours in $\mathrm{GA}_{3}$ solutions of each concentration and water. Treatment of polythene bags were done with treated with the help of fungicide. The seeds were sown in polythene bags of (30 $\mathrm{x} 15 \mathrm{~cm}$ ) filled with a mixture of soil, sand, FYM in the ratio of $1: 1: 1$. The sowing of custard apple seeds was done on $2^{\text {nd }}$ November 2013. Watering and other operations were done as per requirements.

In this experiment, the response of different concentrations of $\mathrm{GA}_{3}$ and different dates of sowing were evaluated for growth and development of custard apple seedlings. The experiment was laid out in factorial CRD as show in each treatment was replicated thrice randomly. The following observations were recorded at 120 days after sowing. Randomly selected three plants were tagged for following observations:

Fresh weight of root $(\mathrm{g})$

Dry weight of root $(\mathrm{g})$

Total dry matter production (g)

The fallowing observations were recorded at 30, 60, 90 and 120 days after sowing. Randomly selected five plants were tagged for following observations:

Height of plant (cm) - Height was measured from ground level to the tip of opened leaf.

Girth of stem (mm) - The girth of stem was measured with the help of digital veneer 
calipers just above the ground surface and the average was calculated.

Number of leaves per seedling - The total number of leaves per seedling was counted and the average was calculated. Matured leaves were taken into account.

\section{Results and Discussion}

The findings are briefly discussed and interpreted with the support of the finding of the previous research work.

\section{Fresh weight of $\operatorname{root}(\mathrm{g})$}

The data presented in Table 2 showed that when seeds were treated with $500 \mathrm{ppm} \mathrm{GA}_{3}$, the fresh weight of roots with increased $(0.75 \mathrm{~g})$ at 120 days after germination and it minimum $(0.53 \mathrm{~g})$ when the seed are treated $\left(G_{0}\right)$. The sowing date $D_{4}$ indicated the maximum fresh weight of root while the sowing date $\mathrm{D}_{1}$ indicated the minimum fresh weight of root. On the other hand, when $500 \mathrm{ppm} \mathrm{GA}_{3}$ treated seed were sown in $\left(\mathrm{G}_{3} \mathrm{D}_{4}\right)$ the fresh weight of roots was increased maximum $(0.96 \mathrm{~g})$ and fresh weight of roots was minimum when untreated $\left(\mathrm{G}_{0} \mathrm{D}_{1}\right)$ seeds were sown on $2^{\text {nd }}$ November (FES). Increase in fresh weight of root with increasing $\mathrm{GA}_{3}$ concentration may be due to increased auxin level in the roots which stimulated more root initiation, more nutrient uptake and root cell elongation, thus resulting into increased tap root length and number of secondary and fibrous roots and in return increased the fresh and dry weight. These results are in corroborated with the findings of Randhawa $e t$ al., (1959), Shanmugavelu (1971) and (Ratan and Reddy (2004).

\section{Dry weight of root $(\mathrm{g})$}

The data regarding dry weight of roots as influenced by various concentrations of $\mathrm{GA}_{3}$ and sowing dates presented in Table 2indicated that the maximum dry weight of root $(0.20 \mathrm{~g})$ was obtained at 120 days after germination under 500ppm GA $\mathrm{pA}_{3}$ treatment and Minimum $(0.11 \mathrm{~g})$ was observed under treatment $\mathrm{G}_{0}$. Among different sowing dates $\mathrm{D}_{4}$ recorded maximum $(0.24 \mathrm{~g})$ dry weight of roots, while $\mathrm{D}_{1}$ recorded minimum $(0.08 \mathrm{~g})$ mean dry weight of roots. The interaction effect of $\mathrm{GA}_{3}$ and dates of sowing was found significant. Under the combination of treatments $\mathrm{G}_{3} \mathrm{D}_{4}(0.29)$ significantly maximum dry weight of roots was found at 120 days after germination and minimum was found under $G_{0} D_{1}$. Similar results were also reported by Shanmugavelu (1971).

\section{Table.1 Details of treatment combinations}

\begin{tabular}{|c|c|c|c|c|c|}
\hline $\mathrm{T}_{1}$ & $\mathrm{D}_{1} \mathrm{G}_{0}$ & FES + control & $\mathrm{T}_{9}$ & $\mathrm{D}_{3} \mathrm{G}_{0}$ & 6 day AES + control \\
\hline $\mathrm{T}_{2}$ & $\mathrm{D}_{1} \mathrm{G}_{1}$ & $\mathrm{FES}+200 \mathrm{ppm} \mathrm{GA}_{3}$ & $\mathrm{~T}_{10}$ & $\mathrm{D}_{3} \mathrm{G}_{1}$ & 6 day $\mathrm{AES}+200 \mathrm{ppm} \mathrm{GA}_{3}$ \\
\hline $\mathrm{T}_{3}$ & $\mathrm{D}_{1} \mathrm{G}_{2}$ & $\mathrm{FES}+400 \mathrm{ppm} \mathrm{GA}_{3}$ & $\mathrm{~T}_{11}$ & $\mathrm{D}_{3} \mathrm{G}_{2}$ & 6 day $\mathrm{AES}+400 \mathrm{ppm} \mathrm{GA}_{3}$ \\
\hline $\mathrm{T}_{4}$ & $\mathrm{D}_{1} \mathrm{G}_{3}$ & $\mathrm{FES}+500 \mathrm{ppm} \mathrm{GA} 3$ & $\mathrm{~T}_{12}$ & $\mathrm{D}_{3} \mathrm{G}_{3}$ & 6 day $\mathrm{AES}+500 \mathrm{ppm} \mathrm{GA}_{3}$ \\
\hline $\mathrm{T}_{5}$ & $\mathrm{D}_{2} \mathrm{G}_{0}$ & 3 day AES + control & $\mathrm{T}_{13}$ & $\mathrm{D}_{4} \mathrm{G}_{0}$ & 9 day AES + control \\
\hline $\mathrm{T}_{6}$ & $\mathrm{D}_{2} \mathrm{G}_{1}$ & 3 dayAES + 200ppm GA 3 & $\mathrm{~T}_{14}$ & $\mathrm{D}_{4} \mathrm{G}_{1}$ & 9 day $\mathrm{AES}+200 \mathrm{ppm} \mathrm{GA}_{3}$ \\
\hline $\mathrm{T}_{7}$ & $\mathrm{D}_{2} \mathrm{G}_{2}$ & 3 day $\mathrm{AES}+400 \mathrm{ppm} \mathrm{GA}_{3}$ & $\mathrm{~T}_{15}$ & $\mathrm{D}_{4} \mathrm{G}_{2}$ & 9 day $\mathrm{AES}+400 \mathrm{ppm} \mathrm{GA}_{3}$ \\
\hline $\mathrm{T}_{8}$ & $\mathrm{D}_{2} \mathrm{G}_{3}$ & 3 day $\mathrm{AES}+500 \mathrm{ppm} \mathrm{GA}_{3}$ & $\mathrm{~T}_{16}$ & $\mathrm{D}_{4} \mathrm{G}_{3}$ & 9 day $\mathrm{AES}+500 \mathrm{ppm} \mathrm{GA}$ \\
\hline
\end{tabular}


Table.2 Influence of $\mathrm{GA}_{3}$ and date of sowing on fresh weight of root, dry weight of root and total dry matter production $(\mathrm{g})$ at 120 day after germination

\begin{tabular}{|c|c|c|c|}
\hline Treatments & $\begin{array}{c}\text { Fresh weight of root } \\
\text { (g) }\end{array}$ & $\begin{array}{l}\text { Dry weight of root } \\
\text { (g) }\end{array}$ & $\begin{array}{c}\text { Total dry matter } \\
\text { production }(\mathrm{g})\end{array}$ \\
\hline$D_{1}$ & 0.45 & 0.08 & 0.199 \\
\hline$D_{2}$ & 0.61 & 0.15 & 0.228 \\
\hline $\mathbf{D}_{3}$ & 0.71 & 0.18 & 0.261 \\
\hline $\mathbf{D}_{4}$ & 0.87 & 0.24 & 0.370 \\
\hline SEm \pm & 0.00 & 0.003 & 0.004 \\
\hline CD at $5 \%$ & 0.01 & 0.008 & 0.012 \\
\hline $\mathbf{G}_{\mathbf{0}}$ & 0.53 & 0.11 & 0.168 \\
\hline $\mathbf{G}_{1}$ & 0.65 & 0.15 & 0.222 \\
\hline $\mathbf{G}_{2}$ & 0.71 & 0.18 & 0.292 \\
\hline $\mathbf{G}_{3}$ & 0.75 & 0.20 & 0.376 \\
\hline SEm \pm & 0.00 & 0.003 & 0.004 \\
\hline CD at $5 \%$ & 0.01 & 0.008 & 0.012 \\
\hline$D_{1} G_{0}$ & 0.33 & 0.04 & 0.107 \\
\hline$D_{1} G_{1}$ & 0.44 & 0.07 & 0.173 \\
\hline$D_{1} G_{2}$ & 0.51 & 0.10 & 0.220 \\
\hline$D_{1} G_{3}$ & 0.54 & 0.12 & 0.297 \\
\hline $\mathbf{D}_{2} \mathbf{G}_{0}$ & 0.48 & 0.09 & 0.150 \\
\hline $\mathbf{D}_{2} \mathbf{G}_{1}$ & 0.62 & 0.15 & 0.187 \\
\hline$D_{2} G_{2}$ & 0.65 & 0.17 & 0.247 \\
\hline $\mathbf{D}_{2} \mathbf{G}_{3}$ & 0.69 & 0.19 & 0.327 \\
\hline $\mathbf{D}_{3} \mathbf{G}_{0}$ & 0.53 & 0.12 & 0.147 \\
\hline $\mathbf{D}_{3} \mathbf{G}_{1}$ & 0.70 & 0.17 & 0.210 \\
\hline$D_{3} G_{2}$ & 0.80 & 0.20 & 0.287 \\
\hline $\mathbf{D}_{3} \mathbf{G}_{3}$ & 0.84 & 0.23 & 0.400 \\
\hline $\mathrm{D}_{4} \mathbf{G}_{0}$ & 0.77 & 0.21 & 0.270 \\
\hline $\mathbf{D}_{4} \mathbf{G}_{1}$ & 0.85 & 0.23 & 0.317 \\
\hline $\mathrm{D}_{4} \mathbf{G}_{2}$ & 0.90 & 0.26 & 0.413 \\
\hline$D_{4} G_{3}$ & 0.96 & 0.29 & 0.480 \\
\hline SEm \pm & 0.00 & 0.006 & 0.008 \\
\hline CD at $5 \%$ & 0.02 & 0.017 & 0.24 \\
\hline
\end{tabular}


Table.3 Influence of $\mathrm{GA}_{3}$ and date of sowing on plant height $(\mathrm{cm})$ at different successive growth stages after germination

\begin{tabular}{|c|c|c|c|c|}
\hline \multirow[t]{2}{*}{ Treatments } & \multicolumn{4}{|c|}{ Plant height (cm) } \\
\hline & $\begin{array}{l}30 \text { days after } \\
\text { germination }\end{array}$ & $\begin{array}{l}60 \text { days after } \\
\text { germination }\end{array}$ & $\begin{array}{l}90 \text { days after } \\
\text { germination }\end{array}$ & $\begin{array}{l}120 \text { days } \\
\text { after } \\
\text { germination }\end{array}$ \\
\hline$D_{1}$ & 1.71 & 3.45 & 7.14 & 8.93 \\
\hline$D_{2}$ & 3.08 & 4.23 & 8.01 & 10.88 \\
\hline $\mathbf{D}_{3}$ & 4.22 & 5.20 & 10.32 & 12.13 \\
\hline $\mathbf{D}_{4}$ & 5.01 & 6.92 & 10.96 & 13.99 \\
\hline SEm \pm & 0.04 & 0.06 & 0.09 & 0.12 \\
\hline CD at $5 \%$ & 0.13 & 0.17 & 0.27 & 0.34 \\
\hline $\mathbf{G}_{\mathbf{0}}$ & 2.80 & 4.21 & 8.30 & 10.08 \\
\hline $\mathbf{G}_{1}$ & 3.14 & 4.63 & 8.97 & 11.15 \\
\hline $\mathbf{G}_{2}$ & 3.84 & 5.31 & 9.36 & 11.84 \\
\hline $\mathbf{G}_{3}$ & 4.24 & 5.64 & 9.79 & 12.86 \\
\hline SEm \pm & 0.04 & 0.06 & 009 & 0.12 \\
\hline CD at $5 \%$ & 0.13 & 0.17 & 0.27 & 0.34 \\
\hline $\mathbf{D}_{1} \mathbf{G}_{0}$ & 1.18 & 3.24 & 6.50 & 7.44 \\
\hline$D_{1} G_{1}$ & 1.55 & 3.27 & 6.87 & 8.88 \\
\hline $\mathbf{D}_{1} \mathbf{G}_{2}$ & 1.82 & 3.51 & 7.36 & 9.53 \\
\hline $\mathbf{D}_{1} \mathbf{G}_{3}$ & 2.29 & 3.77 & 7.83 & 9.88 \\
\hline $\mathbf{D}_{2} \mathbf{G}_{\mathbf{0}}$ & 2.45 & 3.85 & 6.60 & 9.68 \\
\hline $\mathbf{D}_{2} \mathbf{G}_{1}$ & 2.47 & 3.94 & 8.01 & 10.12 \\
\hline $\mathbf{D}_{2} \mathbf{G}_{2}$ & 3.62 & 4.31 & 8.30 & 11.57 \\
\hline$D_{2} G_{3}$ & 3.79 & 4.84 & 9.15 & 12.16 \\
\hline $\mathbf{D}_{3} \mathbf{G}_{0}$ & 3.66 & 4.03 & 9.95 & 10.91 \\
\hline $\mathbf{D}_{3} \mathbf{G}_{1}$ & 3.89 & 4.84 & 10.33 & 11.91 \\
\hline $\mathbf{D}_{3} \mathbf{G}_{2}$ & 4.36 & 5.89 & 10.50 & 12.14 \\
\hline $\mathbf{D}_{3} \mathbf{G}_{3}$ & 5.00 & 6.06 & 10.51 & 13.59 \\
\hline $\mathbf{D}_{4} \mathbf{G}_{0}$ & 3.92 & 5.73 & 10.18 & 12.32 \\
\hline $\mathbf{D}_{4} \mathbf{G}_{1}$ & 4.67 & 6.50 & 10.66 & 13.70 \\
\hline $\mathbf{D}_{4} \mathbf{G}_{2}$ & 5.59 & 7.55 & 11.30 & 14.14 \\
\hline$D_{4} G_{3}$ & 5.87 & 7.90 & 11.69 & 15.83 \\
\hline SEm \pm & 0.09 & 0.12 & 0.18 & 0.24 \\
\hline CD at $5 \%$ & 0.27 & 0.34 & 0.54 & 0.69 \\
\hline
\end{tabular}


Table.4 Influence of $\mathrm{GA}_{3}$ and date of sowing on girth of stem $(\mathrm{mm})$ at different successive growth stages after germination

\begin{tabular}{|c|c|c|c|c|}
\hline \multirow[t]{2}{*}{ Treatments } & \multicolumn{4}{|c|}{ Girth of stem (mm) } \\
\hline & $\begin{array}{l}30 \text { days after } \\
\text { germination }\end{array}$ & $\begin{array}{l}60 \text { days after } \\
\text { germination }\end{array}$ & $\begin{array}{l}90 \text { days after } \\
\text { germination }\end{array}$ & $\begin{array}{l}120 \text { days } \\
\text { after } \\
\text { germination }\end{array}$ \\
\hline$D_{1}$ & 0.84 & 1.64 & 2.60 & 3.61 \\
\hline$D_{2}$ & 1.04 & 1.72 & 2.66 & 4.01 \\
\hline $\mathbf{D}_{3}$ & 0.95 & 1.82 & 2.73 & 4.35 \\
\hline $\mathbf{D}_{4}$ & 1.39 & 2.14 & 3.32 & 4.76 \\
\hline SEm \pm & 0.01 & 0.04 & 0.64 & 0.04 \\
\hline CD at $5 \%$ & 0.02 & 0.14 & 0.19 & 0.14 \\
\hline $\mathbf{G}_{\mathbf{0}}$ & 0.95 & 1.72 & 2.62 & 3.81 \\
\hline $\mathbf{G}_{1}$ & 1.01 & 1.75 & 2.84 & 3.99 \\
\hline $\mathbf{G}_{2}$ & 1.05 & 1.75 & 2.91 & 4.25 \\
\hline $\mathbf{G}_{3}$ & 1.20 & 2.10 & 2.93 & 4.68 \\
\hline SEm \pm & 0.01 & 0.04 & 0.64 & 0.04 \\
\hline CD at $5 \%$ & 0.02 & 0.14 & 0.19 & 0.14 \\
\hline $\mathbf{D}_{1} \mathbf{G}_{0}$ & 0.69 & 1.66 & 2.35 & 3.25 \\
\hline$D_{1} G_{1}$ & 0.93 & 1.72 & 2.67 & 3.56 \\
\hline$D_{1} G_{2}$ & 0.77 & 1.33 & 2.73 & 3.79 \\
\hline$D_{1} \mathbf{G}_{3}$ & 0.95 & 1.85 & 2.60 & 3.85 \\
\hline $\mathbf{D}_{2} \mathbf{G}_{\mathbf{0}}$ & 0.99 & 1.58 & 2.41 & 4.18 \\
\hline $\mathbf{D}_{2} \mathbf{G}_{1}$ & 1.16 & 1.70 & 2.96 & 3.73 \\
\hline $\mathbf{D}_{2} \mathbf{G}_{2}$ & 1.05 & 1.75 & 2.64 & 3.76 \\
\hline $\mathbf{D}_{2} \mathbf{G}_{3}$ & 0.95 & 1.87 & 2.65 & 4.35 \\
\hline $\mathbf{D}_{3} \mathbf{G}_{0}$ & 0.99 & 1.71 & 2.73 & 3.82 \\
\hline $\mathbf{D}_{3} \mathbf{G}_{1}$ & 0.86 & 1.63 & 2.36 & 3.98 \\
\hline $\mathbf{D}_{3} \mathbf{G}_{2}$ & 0.95 & 1.64 & 2.93 & 4.52 \\
\hline $\mathbf{D}_{3} \mathbf{G}_{3}$ & 0.99 & 2.29 & 2.89 & 5.07 \\
\hline $\mathbf{D}_{4} \mathbf{G}_{\mathbf{0}}$ & 1.15 & 1.93 & 3.03 & 4.01 \\
\hline $\mathbf{D}_{4} \mathbf{G}_{1}$ & 1.09 & 1.95 & 3.36 & 4.63 \\
\hline $\mathbf{D}_{\mathbf{4}} \mathbf{G}_{2}$ & 1.42 & 2.28 & 3.33 & 4.94 \\
\hline $\mathbf{D}_{4} \mathbf{G}_{3}$ & 1.92 & 2.39 & 3.58 & 5.45 \\
\hline SEm \pm & 0.02 & 0.09 & 0.13 & 0.09 \\
\hline CD at $5 \%$ & 0.05 & 0.28 & 0.37 & 0.28 \\
\hline
\end{tabular}


Table.5 Influence of $\mathrm{GA}_{3}$ and date of sowing on number of leaves per seedling at different successive growth stages after germination

\begin{tabular}{|c|c|c|c|c|}
\hline \multirow[t]{2}{*}{ Treatments } & \multicolumn{4}{|c|}{ Number of leaves per seedling } \\
\hline & $\begin{array}{l}30 \text { days after } \\
\text { germination }\end{array}$ & $\begin{array}{l}60 \text { days after } \\
\text { germination }\end{array}$ & $\begin{array}{l}90 \text { days after } \\
\text { germination }\end{array}$ & $\begin{array}{l}120 \text { days } \\
\text { after } \\
\text { germination }\end{array}$ \\
\hline$D_{1}$ & 2.82 & 4.07 & 7.02 & 9.86 \\
\hline$D_{2}$ & 2.95 & 5.28 & 7.40 & 10.40 \\
\hline $\mathbf{D}_{3}$ & 3.44 & 5.33 & 8.21 & 12.37 \\
\hline $\mathbf{D}_{4}$ & 3.71 & 6.02 & 10.02 & 15.17 \\
\hline SEm \pm & 0.07 & 0.07 & 0.09 & 0.15 \\
\hline CD at $5 \%$ & 0.20 & 0.20 & 0.28 & 0.45 \\
\hline $\mathbf{G}_{\mathbf{0}}$ & 1.93 & 3.84 & 6.53 & 9.96 \\
\hline $\mathbf{G}_{1}$ & 3.11 & 4.98 & 8.01 & 11.44 \\
\hline $\mathbf{G}_{2}$ & 3.70 & 5.61 & 8.69 & 12.54 \\
\hline $\mathbf{G}_{3}$ & 4.18 & 6.27 & 9.42 & 13.86 \\
\hline SEm \pm & 0.07 & 0.07 & 0.09 & 0.15 \\
\hline CD at $5 \%$ & 0.20 & 0.20 & 0.28 & 0.45 \\
\hline $\mathbf{D}_{1} \mathbf{G}_{\mathbf{O}}$ & 2.22 & 3.11 & 5.11 & 7.14 \\
\hline$D_{1} G_{1}$ & 2.58 & 3.92 & 6.92 & 9.77 \\
\hline $\mathbf{D}_{1} \mathbf{G}_{2}$ & 3.03 & 4.38 & 7.55 & 10.77 \\
\hline $\mathbf{D}_{1} \mathbf{G}_{3}$ & 3.44 & 4.88 & 8.51 & 11.77 \\
\hline $\mathbf{D}_{2} \mathbf{G}_{\mathbf{0}}$ & 1.40 & 3.99 & 6.42 & 8.99 \\
\hline $\mathbf{D}_{2} \mathbf{G}_{1}$ & 2.88 & 5.24 & 7.33 & 9.99 \\
\hline $\mathbf{D}_{\mathbf{2}} \mathbf{G}_{2}$ & 3.55 & 5.66 & 7.55 & 10.83 \\
\hline$D_{2} G_{3}$ & 3.99 & 6.22 & 8.33 & 11.81 \\
\hline$D_{3} G_{0}$ & 1.77 & 3.87 & 6.87 & 10.96 \\
\hline $\mathbf{D}_{3} \mathbf{G}_{1}$ & 3.44 & 5.24 & 7.96 & 11.74 \\
\hline $\mathbf{D}_{3} \mathbf{G}_{2}$ & 3.99 & 5.62 & 8.69 & 12.48 \\
\hline $\mathbf{D}_{3} \mathbf{G}_{3}$ & 4.55 & 6.59 & 9.33 & 14.33 \\
\hline$D_{4} G_{0}$ & 2.33 & 4.40 & 7.73 & 12.77 \\
\hline $\mathbf{D}_{4} \mathbf{G}_{1}$ & 3.55 & 5.51 & 9.85 & 14.25 \\
\hline $\mathbf{D}_{\mathbf{4}} \mathbf{G}_{\mathbf{2}}$ & 4.21 & 6.77 & 10.99 & 16.10 \\
\hline $\mathbf{D}_{4} \mathbf{G}_{3}$ & 4.77 & 7.40 & 11.51 & 17.55 \\
\hline SEm \pm & 0.14 & 0.14 & 0.19 & 0.31 \\
\hline CD at $5 \%$ & 0.41 & 0.41 & 0.57 & 0.90 \\
\hline
\end{tabular}

Total dry matter production $(\mathrm{g})$

The data for various treatments with respect to the dry matter recovery are summarized in
Table 2. $\mathrm{G}_{3}\left(500 \mathrm{ppm} \mathrm{GA}_{3}\right)$ was found to record maximum $(0.37 \mathrm{~g})$ dry matter, followed by $\mathrm{G}_{2}(0.29 \mathrm{~g})$ and the minimum $(0.168 \mathrm{~g})$ in $\mathrm{G}_{0}$ (control). 


\section{Girth of stem (mm)}

The findings of stem girth were recorded at different intervals and data summarized in Table 4. When seeds were treated with $500 \mathrm{ppm} \mathrm{GA}_{3}$ increased the mean girth of stem at all stage of observations (1.20, 2.10, 2.93 and $4.68 \mathrm{~mm}$ ) at 30, 60, 90 and 120 days after sowing respectively. Whereas, seeds placed in the rooting media in intervals $(30,60,90$ and 120days) the fourth sowing date is $\mathrm{D}_{4}$ gave maximum girth $(1.39,2.14,3.31$ and $4.76 \mathrm{~mm}$ ) at different intervals respectively. The interaction of $\mathrm{GA}_{3}$ and sowing date $\left(\mathrm{G}_{3} \mathrm{D}_{4}\right)$ maximum mean stem girth (1.92, $2.39,3.58$ and 5.45) at 30, 60, 90 and 120 days was recorded. While girth was observed when untreated seeds sown. The gibberellic acid increases the girth of stem in custard apple mainly due to cell elongation, increase in cell size and rapid cell division. Due to this, the elongation of internodes will takes place, hence the girth of stem will increase. These results are in agreement with the findings of Harshavardhan and Rajsekhar (2012) and (Meena and Jain, 2012).

\section{Number of leaves per seedling}

The data as regarded number of leaves per seedling as influenced by different concentration of $\mathrm{GA}_{3}$ and sowing dates presented in Table 5 indicated that the maximum mean number of leaves per seedlings was produced by the seedling treated with 500ppm $\mathrm{GA}_{3}(4.18,6.27,9.42$ and 13.86) at 30,60, 90 and 120 days after sowing whereas treatment control gave minimum mean number of leaves per seedling at all the stage of observations. Among different sowing dates, $\mathrm{D}_{4}$ encouraged leaf production and gave significantly maximum (3.71, 6.03, 10.02 and 15.17) mean number of leaves per seedling at 30, 60, 90 and 120 days after sowing respectively. The treatment combination $\mathrm{G}_{3} \mathrm{D}_{4}$ produced maximum number of leaves per seedling (i.e. 4.77, 7.40, 9.42 and 17.55$)$ at $30,60,90$ and 120 days after sowing. While number of leaves was reduced when untreated seeds sown. Increase in a number of leaves in $\mathrm{GA}_{3} 500 \mathrm{ppm}$ might be due to the maximum height of seedlings under this treatment. This also helps in invigoration of physiological process of plant and stimulatory effect of chemicals to form new leaves at faster rate as suggested by Shaban (2010). The production of more number of leaves in gibberellic acid treatments may be due to the vigorous growth with more number of branches and leaves which in turn facilitates better harvest of sunshine by the plants to produce more photosynthates. The above results are in conformity with the findings of Pampanna et al., (1995) and (Pal and Dhaka, 2010).

On the basis of findings, it could be concluded that the $\mathrm{GA}_{3}(500 \mathrm{ppm})$ is the best as compare to other $\mathrm{GA}_{3}$ concentrations for influencing the growth and development of seedling. As regards, the sowing dates, $\mathrm{D}_{4}$ were found to be the most suitable sowing date under study for growth and development. However, the $\mathrm{G}_{3} \mathrm{D}_{4}$ gave the most superior results.

\section{References}

Deb, P.A., Das, S.K., Ghosh, C.P. and Suresh. (2010). Improvement of seed germination and seedling growth of papaya (Carica papaya L.) through different pre-sowing seed treatments. Acta Horticulture, (851): 313-316.

Harshavardhana, M. and Rajasekhar, M. (2012). Effect of pre-sowing seed treatments on seedling growth of jackfruit (Artocarpus heterophyllus Lam.). Journal of Research ANGRAU, 40(4): 87-89.

Meena, R.R. and Jain, M.C. (2012). Effect of seed treatment with $\mathrm{GA}_{3}$ on growth 
parameters of papaya seedling (Carica Papaya). Progressive Horticulture, 44(2): 248-250.

Murthy, B.N.S. and Reddy, Y.N. (1990). Temperature dependence of seed germination and seedling growth in ber (Zizyphus mauritiana Lam.) and their modification by pre-sowing treatments. Seed Science and Technology, 18(3): 621-627.

Pal, S.L. and Dhaka, S.S. (2010). Effects of $\mathrm{GA}_{3}$ on germination of seeds and growth of seedlings of sweet orange (Citrus sinensis). Progressive Agriculture, 10(1): 166-167.

Pampanna, Y., Sulikeri, G.S. and Hulmani, N.C. (1995). Effect of growth Regulators on seed germination and growth of seedling of Sapota. Karnataka Journal of Agriculture Science, 8(1): 60-64.

Randhawa, G.S. and Sing, J.P. (1959). Growth response of citrus seedling roots stock to GA. Indian Journal of Horticulture, 116(2): 76-78.

Ratan, P.B. and Reddy, Y.N.(2004). Influence of gibberellic acid on custard apple (Annona squamosa L.) seed germination and subsequent seedling growth. Journal of Research ANGRAU, 32(2): 93-95.

Shaban, A.E.A. (2010). Improving seed germination and seedling growth of some mango rootstocks. AmericanEurasian Journal of Agricultural and Environmental Science, 7 (5): 535-541.

Shanmugavelu, K.G. (1971). Effect of plant growth regulaters of jack (Artocarpus heterophyllus). Madras Agriculture Journal, 58(2): 97-103.

Wagh, A.P., Choudhary, M.H., Kulwal, L.V., Jadhav, B.J. and Joshi, P.S. (1998). Effect of seed treatment on germination of seed and initial growth of aonla seedling in polybag. PKV Research Journal, 22(2): 176-177.

\section{How to cite this article:}

Pritee Rahangdale, S.K. Pandey and Jayswal, D.K. 2019. Influence of $\mathrm{GA}_{3}$ and Date of Sowing on Growth and Development of Custard Apple Seedlings. Int.J.Curr.Microbiol.App.Sci. 8(01): 1813-1821. doi: https://doi.org/10.20546/ijcmas.2019.801.192 